\title{
Antisiperende Labiale Koartikulasie: 'n Elektromiografiese Studie by Afrikaanssprekendes
}

\author{
Karin Theron en Anita van der Merwe
}

\author{
Departement Kommunikasiepatologie \\ Universiteit van Pretoria
}

Malcolm Baker

Departement Neurologie
1 Militêre Hospitaal
Pretoria

\section{OPSOMMING}

Die verskynsel van antisiperende labiale koartikulasie word bestudeer om inligting te bekom aangaande die motoriese beplanning van spraak deur die brein. Die doel van die studie is om inligting te bekom in verband met die temporale omvang van antisiperende labiale koartikulasie, die verloop van koartikulasie vir uitinge wat bestaan uit twee geronde vokale geskei deur 'n nie-labiale konsonant en laastens die effek van 'n woordgrens op die aanvang van koartikulasie by normale Afrikaanssprekende volwassenes. Die metode het bestaan uit die opname van elektromiografiese aktiwiteit vanaf Musculus Orbicularis Oris met 'n bipolêre konsentriese naaldelektrode. Die resultate dui daarop dat antisiperende labiale koartikulasie wel voorkom en dat die aanvang van lipronding toenemend vroeër intree namate die duur van die konsonantstring wat die geronde vokaal voorafgaan toeneem. By die ondersoek van antisiperende labiale koartikulasie in uitings wat bestaan uit twee geronde vokale wat deur 'n nie-labiale konsonant geskei word, is gevind dat twee pieke van elektromiografiese aktiwiteit met ' $n$ duidelike afname in aktiwiteit tussen die pieke voorkom. Laastens is gevind dat antisiperende labiale koartikulasie oor woordgrense kan voorkom. Die resultate word bespreek aan die hand van verskillende teoretiese modelle van spraakproduksie wat poog om die verskynsel van antisiperende labiale koartikulasie te verklaar.

\section{ABSTRACT}

Anticipatory coarticulation sheds light on the planning of speech by the brain. The aim of this study is to gain information on the temporal extent of anticipatory labial coarticulation, the course of coarticulation for utterances consisting of two rounded vowels separated by an intervening consonant without rounding specification and lastly the effect of word boundaries on the onset of coarticulation in normal Afrikaans speaking adults. The method consisted of the recording of electromiographic (EMG) activity from Musculus Orbicularis Oris using a bipolar concentric needle electrode. The results suggested that anticipatory coarticulation is' demonstrated by Afrikaans speaking individuals and that the onset of liprounding for a rounded vowel commenced earlier when the duration of the nonlabial consonantal string preceding the rounded vowel increased. During the investigation of anticipatory labial coarticulation in utterances consisting of two rounded vowels separated by a nonlabial consonant, it was found that two peaks in EMG activity with a pronounced decrease in activity between the peaks occurred. Lastly it was found that anticipatory coarticulation can occur across word boundaries. The results are discussed in relation to different theoretical models of speech production which have been proposed to account for the phenomenon of anticipatory labial coarticulation.

SLEUTELWOORDE: antisiperende koartikulasie, elektromiografiese aktiwiteit, motoriese beplanning, teoretiese modelle van spraakproduksie

Beplanning van spraak word nog dikwels as 'n hipotetiese en kontroversiële konsep beskou, omdat daar nie 'n objektiewe meetinstrument bestaan wat beplanning kan meet nie. Baie bewyse word egter aangevoer vir die voorafbeplanning van spraak. By normale sprekers suggereer onbewuste woord-'en foneemomruilings, "spoon- erisms", dat 'n spreker'n volledige frase in gereedheid het voordat dit geuiter word (Harris 1984; Borden \& Harris, 1984). Antisiperende koartikulasie reflekteer die omvang van vooruitbeplanning van komende segmente (Katz, $1988 \mathrm{a} ; 1988 \mathrm{~b}$ ) en aangesien koartikulasie ekstern gemanifesteer word, is dit meetbaar en word dit bestudeer 
om inligting te verskaf aangaande die grootte en aard van die eenhede wat as invoer vir die motoriese beplanning van spraak gebruik word (Kent \& Minifie, 1977; Lubker, 1981; Lubker \& Gay, 1982; Katz, Machetanz, Schönle \& Orth, 1990). Studies aangaande antisiperende labiale koartikulasie is tot op datum in tale soos Sweeds, Russies, Frans en Engels uitgevoer, maar daar bestaan nog 'n leemte t.o.v. die bestudering van hierdie verskynsel in Afrikaans. Aangesien daar nog baie kontroversie in die literatuur bestaan omtrent sekere kernaspekte van antisiperende labiale koartikulasie is verdere studies nodig om hierdie aspekte te ondersoek en om die universaliteit daarvan te bepaal. Verder is dit noodsaaklik om antisiperende koartikulasie by normaalsprekende persone te bestudeer, want eers wanneer 'n verwysingsraamwerk van normale koartikulasie daargestel is kan neuromotoriese afwykings, veral in die beplanning van spraak, binne hierdie raamwerk bestudeer word.

Antisiperende koartikulasie word as 'n inherente deel van die neuromotoriese beplanning van spraak beskou. Die beplanning veroorsaak dat die artikulators geaktiveer word en sodoende kan 'n artikulatoriese doelwit van 'n komende segment bereik word voordat dit akoesties gerealiseer word (Sussmann, Marquardt, MacNeilage \& Hutchinson, 1988). Borden en Harris (1984) definieer koartikulasie as die temporale oorvleueling van artikulatoriese bewegings vir verskillende foneme. Antisiperende labiale koartikulasie verwys spesifiek na die vroeë aanset van kenmerke wat verband hou met labialiteit, bv. die aanset van ronding vir geronde vokale (Lubker \& Gay, 1982).

Die temporale en ruimtelike aspekte van linguale, labiale, velêre en mandibulêre koartikulasie is al vanaf die 1960's bestudeer. Die eksperimentele metode behels gewoonlik die kontrolering van een of twee fisiologiese aanduiders van neuromuskulêre aktiwiteit, tesame met die ouditief waarneembare spraaksein. Die fisiologiese metings word verkry deur bv. kineradiografiese ontleding (bv. verplasing van die tong of velum) of elektromiografiese (EMG) metings vanaf die toepaslike agonisspier(e) verantwoordelik vir die artikulatoriese beweging (bv. die Orbicularis Oris vir lipronding) (Sussmann et al., 1988; Blair \& Smith, 1986).

Een van die aspekte van antisiperende labiale koartikulasie wat al dikwels bestudeer is, is die temporale omvang van die antisipering. Deur die aspek te bestudeer word inligting ingewin aangaande die grootte en aard van die eenhede wat die brein gebruik in die motoriese beplanning van spraak, asook inligting aangaande die kontrole en ordening van die eenhede (Lubker, 1981; Lubker \& Gay, 1982; Katz, 1988a; 1988b; Katz et al., 1990).

Daar is tans twee opponerende sienings aangaande die temporale omvang van antisiperende labiale koartikulasie. Die een groep navorsers meen dat 'n persoon labiale beweging vir 'n geronde vokaal beplan in verhouding tot die duur van die foneme wat dit voorafgaan (Daniloff \& Moll, 1968; Benguerel \& Cowan, 1974; Lubker, 1981; Sussmann \& Westbury, 1981). Volgens hierdie navorsers kan antisiperende labiale koartikulasie 'n redelik wye omvang hê. Benguerel en Cowan (1974) het gevind dat lipprotrusie vir Franse geronde vokale soveel as ses konsonante voor die akoestiese aanset van die geronde vokaal voorkom. Daniloff en Moll (1968) het weer gevind dat lipronding in Engels tot vier konsonante voor die akoestiese aanset van die geronde vokaal' $n$ aanvang neem.
Waar die bogenoemde navorsers die hoeveelheid konsonante bepaal het waaroor antisiperende labiale koartikulasie kan strek, het Lubker (1981) die tydsverloop in millisekondes bepaal vanaf die aanset van EMG aktiwiteit geassosieer met lipronding tot by die akoestiese aanset van die geronde vokaal. $\mathrm{Hy}$ het gevind dat labiale EMG aktiwiteit vir Sweedse geronde vokale tot $600 \mathrm{~ms}$ voor die akoestiese aanvang van die geronde vokaal kan begin (McAllister, Lubker \& Carlson, 1974; Lubker, 1981).

Die wye omvang van antisiperende labiale koartikulasie impliseer dat die brein 'n bespiedingsproses uitvoer op die uiting wat geproduseer gaan word. Hierdie vermoë van die brein om so 'n bespiedingsmeganisme te implementeer tydens die motoriese beplanning van spraak is deur Henke (in Kent \& Minifie, 1977) gepostuleer in 'n spraakproduksiemodel wat as Henke se bespiedingsmodel bekend staan. Henke spesifiseer egter nie die temporale omvang van die bespiedingsgebeure nie en meen dat ' $n$ komende kenmerk soos ronding deur al die foneme wat die geronde klank voorafgaan, geantisipeer sal word, solank die voorafgaande kenmerke nie antagonisties is t.o.v. die bepaalde kenmerk nie.

Die ander groep navorsers postuleer dat antisiperende koartikulasie nie so 'n wye omvang kan hê nie en dat die aanset van die rondingsbeweging geassosieer met die geronde vokaal beperk is tot 'n relatief klein temporale venster van ongeveer 250ms (Bell-Berti \& Harris, 1979; $1981 ; 1982$ ). Hierdie aanname impliseer dat lipronding op 'n vasgestelde tyd voor die aanvang van'n geronde vokaal 'n aanvang sal neem. Die aanvang van die lipronding sal dus nie wissel na gelang van die lengte van die konsonantstring wat die geronde vokaal voorafgaan nie (Gay 1979; Bell-Berti \& Harris, 1979; 1981; 1982).

Die kontroversie wat gegenereer word deur die opponerende sienings is van besondere belang in spraaknavorsing, aangesien dit verskillende verduidelikings van die motoriese organisasie van antisiperende koartikulasie gee (Lubker \& Gay, 1982). Die eerste siening impliseer dat die brein die motoriese kontroleprogram vir die aanset van labiale aktiwiteit versigtig beplan en aanpas by die duur van die konsonantstring wat die geronde vokaal voorafgaan. Laasgenoemde siening onderskryf dus die werking van 'n bespiedingsmeganisme tydens die motoriese beplanning van spraak. Die tweede siening postuleer die bestaan van 'n vaste en relatief kon'stante (dalk $250 \mathrm{~ms}$ ) "tydsvenster" waar die brein nie genoodsaak word om enige fyn aanpassings t.o.v. temporale aanset te mak nie. Wanneer 'n labiale rondingsbeweging benodig word, word dit op 'n vasgestelde tyd voor die geronde vokaal geïnisieer en die duur van die voorafgaande konsonantstring is dus irrelevant (Lubker \& Gay, 1982).

Nog 'n aspek van antisiperende koartikulasie wat dikwels bestudeer word, is die voorkoms van koartikulasie vanaf een geronde vokaal na'n ander waar die twee vokale geskei word deur tussenkomende nie-labiale konsonante wat nie met ronding geproduseer word nie $\left(\mathrm{V}_{\mathrm{g}} \mathrm{K}_{\mathrm{nl}} \mathrm{V}_{\mathrm{g}}-\right.$ konteks). In sulke gevalle het albei bogenoemde, opponerende groepe navorsers gevind dat 'n keep in die elektromiografiese aktiwiteit voorkom. Twee duidelike pieke in EMG aktiwiteit met 'n totale staking of noemenswaardige vermindering in EMG-aktiwiteit tussen die pieke word in die foneemkonteks onderskei. Die keepverskynsel impliseer dat antisiperende labiale koartikulasie afwesig is in die $\mathrm{V}_{\mathrm{g}} \mathrm{K}_{\mathrm{n}} \mathrm{V}_{\mathrm{g}}$-konteks. Indien antisiperende labiale koartikulasie kan voorkom oor 
foneemstringe van tot vyf of ses konsonante (Benguerel \& Cowan, 1974) ontstaan die vraag hoekom dit nie volgehou kan word in $/ V K V /$-uitinge nie, waar $V=/ w /$ en die vokale deur slegs een konsonant geskei word.

Navorsers wat meen dat antisiperende labiale koartikulasie beperk is tot ' $n$ relatief klein temporale venster en dat die labiale rondingsbeweging dus op 'n vasgestelde tyd voor die aanvang van die geronde vokaal 'n aanvang neem, meen dat die keep- of dubbele piekverskynsel (Lubker \& Gay, 1982) bewys lewer vir hulle aanname. Navorsers wat egter die werking van 'n bespreidingsmeganisme ondersteun, postuleer dat die keepverskynsel slegs daarop dui dat idiosinkratiese aanpassings in beplanning nodig is, afhangende van die eerste vokaal in die segmentreeks (m.a.w. die vokaal wat die geronde vokaal voorafgaan) (Sussmann \& Westbury, 1981). Die afname in lipronding tydens die produksie van die konsonant vóór die tweede geronde vokaal staan dus teenoor die werking van die bespiedingsmodel vir spraakproduksie soos voorgestel deur Henke (in Kent \& Minifie, 1977; Bell-Berti \& Harris, 1974; Gay, 1979).

'n Ander aspek van antisiperende koartikulasie wat al dikwels bestudeer is, is die invloed van 'n woordgrens op die aanvang van koartikulasie. Sommige navorsers het gevind dat die woordgrens nie die aanvang van die rondingsbeweging beïnvloed nie (Daniloff \& Moll, 1968; Benguerel \& Cowan, 1974; Bell-Berti \& Harris, 1982). Ander het weer gevind dat sekere linguistiese grense wel 'n effek het (McLean, 1973).

'n Spraakproduksiemodel, wat o.a. poog om die verskynsel van antisiperende koartikulasie te verklaar, is deur Kozhevnikov en Chistovich (in Kent \& Minifie, 1977 ) voorgestel. Die navorsers voer aan dat die invoereenheid vir die motoriese beplanning van spraak'n artikulatoriese lettergreep is, wat bestaan uit enige hoeveelheid konsonante gevolg deur 'n vokaal, en dat die lettergreepgrens 'n beperking plaas op antisiperende koartikulasie. Indien koartikulasie egter nie deur die woord- of lettergreepgrens beïnvloed word nie, kan die artikulatoriese lettergreepmodel van Kozhevnikov en Chistovich (in Kent \& Minifie, 1977) nie sonder meer aanvaar word nie. 'n Verdere afleiding wat gemaak kan word indien die woordgrens nie die aanvang van antisiperende koartikulasie beïnloed nie, is dat die brein se linguisties-simboliese beplanning van spraak afsonderlik van die motoriese beplanning van 'n uiting plaasvind (Van der Merwe, 1986).

Dit is dus duidelik dat daar 'n behoefte bestaan aan verdere ondersoek van sekere aspekte van antisiperende labiale koartikulasie, aangesien daar steeds kontroversie in die literatuur heers oor die voorkoms en aard daarvan. Verder is geen studies m.b.t. antisiperende labiale koartikulasie al met Afrikaanssprekende persone uitgevoer nie en is dit dus nodig om hierdie verskynsel te ondersoek ten einde te bepaal of die voorkoms en aard daarvan universeel is.

\section{METODE}

\section{DOELSTELLINGS}

Die doel van die studie is om inligting te bekom aangaande spesifieke aspekte van antisiperende labiale koartikulasie by Afrikaanssprekende normale sprekers, ten einde afleidings te maak aangaande die motoriese beplanning van spraak deur die brein. Die volgende aspekte word ondersoek:
- Die temporale omvang van antisiperende labiale koartikulasie. Die doel is dus om te bepaal of die aanvang van labiale beweging, geassosieer met ronding, beplan word in verhouding tot die duur van die nie-labiale konsonantstring wat die geronde vokaal voorafgaan (wye omvang) en of die labiale rondingsbeweging telkens 'n vasgestelde tyd voor die aanvang van die geronde vokaal geïnisieer word (beperkte omvang). Hierdie aspek sal dus inligting verskaf aangaande die grootte en aard van die invoereenheid wat die brein gebruik in die motoriese beplanning van spraak.

- Die verloop van elektromiografiese (EMG) aktiwiteit vir uitinge wat bestaan uit twee geronde vokale wat deur 'n nie-labiale konsonant geskei word $\left(\mathrm{V}_{\mathrm{g}} \mathrm{K}_{\mathrm{nl}} \mathrm{V}_{\mathrm{s}}\right.$ konteks). Verskeie navorsers (Gay, 1979; Bell-Berti \& Harris, 1982) het gevind dat antisiperende labiale koartikulasie in hierdie foneemkonteks afwesig is. Laasgenoemde bevinding sal dus die werking van 'n bespiedingsmeganisme tydens diè motoriese beplanning van spraak teenstaan.

- Die effek van woordgrense op die aanvang van die labiale rondingsbeweging. Daar word eerstens bepaal of antisiperende labiale koartikulasie oor woordgrense sal voorkom en of 'n woordgrens die voorkoms van antisiperende labiale koartikulasie gedurende die eerste woord van 'n tweewoorduiting inhibeer soos gepostuleer deur Kozhevnikov en Chistovich (in Kent \& Minifie, 1977). Vervolgens word bepaal of die aanvangsmoment van ronding beïnvloed word deur die woordgrense vir uitinge waar 'n sekere konsonantkombinasie binne 'n woord en oor'n woordgrens voorkom.

\section{NAVORSINGSONTWERP}

Die onderskeie doelstellings het telkens dieselfde eksperimentele ontwerp. Dieselfde respondente is vir al drie die ondersoeke gebruik. Die ontwerp bestaan telkens uit een of twee eksperimentele materiaalgroepe met 'n kontrole materiaalgroep (Guy, Edgley, Arafat \& Allen, 1987). Die eksperimentele materiaalgroep verwys na uitings waarin 'n geronde vokaal voorkom. Sekere handelings is met die eksperimentele, sowel as die kontrole materiaalgroep uitgevoer, waar die handeling telkens bestaan het uit die lees van 'n spesifieke uiting vanaf 'n kaartjie. Die kontrole materiaalgroep verwys na uitings waarin daar nie'n geronde vokaal voorgekom het nie. Die kontrole materiaalgroep was telkens soortgelyk aan die eksperimentele materiaalgroep, maar in die plek van die geronde vokaal het die kontrole materiaalgroep die hoë voorvokaal $/ \mathrm{i}$, wat met lipstrekking geproduseer word, bevat. Die kontrole materiaalgroep is ingesluit om te kontroleer dat labiale EMG-aktiwiteit wat tydens die produksie van die eksperimentele materiaalgroep opgeteken word, wel voorkom a.g.v. die teenwoordigheid van die geronde vokaal. Die onderskeie doelstellings en handelings toegepas binne die eksperimentele en kontrole materiaalgroepe verskyn in Tabel 1.

\section{PROEFPERSONE}

Die proefpersone het 5 normaalsprekende persone sonder enige geskiedenis van spraak- of neurologiese afwykings ingesluit. Die proefpersone moes oor normale gehoor en intelligensie beskik en tussen die ouderdomme 19 en 25 jaar wees. Almal was sprekers van standaard Afrikaans. 
Tabel 2 verskaf' 'n opsommende weergawe van die kenmerke van die proefpersone.

\section{APPARAAT}

Vir die opname van die elektromiografiese (EMG) potensiale vanaf Musculus Orbicularis Oris is gebruik gemaak van 'n bipolêre konsentriese naaldelektrode wat gekoppel is aan kanaal 1 van 'n multikanaal elektromiograaf, Medelec Mystro MS25. Daar is gebruik gemaak van'n bipolêre naaldelektrode, aangesien die tipe elektrode EMG-aktiwiteit binne 'n baie klein gebied kan bepaal.

Die spraaksein is opgeneem deur 'n mikrofoon, Pro 2 Dynamic Microphone met ' $n$ impedans van $300 U$ w wat aan kanaal 2 van die elektromiograaf gekoppel is en 'n visuele voorstelling van die spraaksein tot gevolg gehad het. Daar is spesiaal deur' $n$ tegnikus 'n spraakprogram vir opname van die akoestiese sein, geinstalleer.

Die Medelec Mystro MS25 besit'n funksie vir die direkte stoor van resultate. Die elektromiografiese aktiwiteit, op kanaal 1, en die visuele voorstelling van die spraaksein, op kanaal 2, is onder mekaar op die rekenaarskerm van die elektromiograaf vertoon (Figuur 1).

\section{EKSPERIMENTELE EN KONTROLE MATERIAAL}

\section{Motivering vir die keuse van spraakmateriaal}

Eksperimentele materiaal

Die eksperimentele materiaal wat geselekteer is vir die uitvoering van die studie het bestaan uit onsinreekse wat opgestel is om aan die doel van die studie te voldoen. Die reekse is elkeen vyf keer agtereenvolgend gesê en die elektromiograaf is geprogrammeer om telkens die gemiddeld van elke uiting voor te stel vir beide die spraaksein en die EMG-aktiwiteit. Die gemiddeld van vyf herhalings verhoog die betroubaarheid van die resultate. Al die materiaal is so opgestel dat die uiting met ' $n$ stemhebbende klank begin en dat die konsonante wat die stemhebbende geronde vokaal voorafgaan, stemloos is. Sodoende kon daar tydens data analise maklik op die visuele voorstelling van die spraaksein onderskei word tussen die konsonantstring en die aanvang van die geronde vokaal (Figuur 1).

\section{Kontrole materiaal}

Die kontrole materiaal is opgestel om te bepaal of labiale EMG-aktiwiteit, voorkom in segmentreekse wat nie 'n

TABEL 1: Doelstellings en handelings toegepas binne die kontrole en eksperimentele materiaalgroepe.

\begin{tabular}{|c|c|c|c|}
\hline \multirow[t]{2}{*}{ Doelstellings } & \multicolumn{2}{|c|}{$\begin{array}{l}\text { Eksperimentele } \\
\text { materiaalgroep }\end{array}$} & \multirow{2}{*}{$\begin{array}{c}\text { Kontrole } \\
\text { materiaal } \\
\text { groep }\end{array}$} \\
\hline & Groep 1 & Groep 2 & \\
\hline $\begin{array}{l}\text { Bepaling van die temporale omvang van } \\
\text { antisiperende labiale koartikulasie in uitinge met } \\
\text { verskillende konsonantstringduur }\end{array}$ & $\begin{array}{l}\text { /isu/ } \\
\text { /istu/ } \\
\text { /istsu/ } \\
\text { /iststu/ } \\
\text { /ikststu/ }\end{array}$ & $\begin{array}{l}\text { /is } \supset / \\
\text { /ist } \supset / \\
\text { /ists } \supset / \\
\text { /istst } \supset / \\
\text { /ikstst } \supset /\end{array}$ & $\begin{array}{l}\text { /isi/ } \\
\text { /isti/ } \\
\text { /istsi/ } \\
\text { /iststi/ } \\
\text { /ikststi/ }\end{array}$ \\
\hline $\begin{array}{l}\text { Bepaling van die verloop van elektromiografiese } \\
\text { aktiwiteit in die } \mathrm{V}_{\mathrm{g}} \mathrm{K}_{\mathrm{nl}} \mathrm{V}_{\mathrm{g}} \text {-konteks }\end{array}$ & $\begin{array}{l}\text { /usu/ } \\
\text { /uku/ }\end{array}$ & & $\begin{array}{l}\text { /isi/ } \\
\text { /iki/ }\end{array}$ \\
\hline $\begin{array}{l}\text { Bepaling van die effek van woordgrense op die } \\
\text { aanvang van die labiale rondingsbeweging }\end{array}$ & $\begin{array}{l}\text { /gistul/ } \\
\text { /gistut// } \\
\text { /gistup/ } \\
\text { /gist } \supset f / \\
\text { /gistつl/ } \\
\text { /gist } \supset m /\end{array}$ & $\begin{array}{l}/ \mathrm{dis} / / \text { tuld/ } \\
/ \mathrm{dis} / / \text { tutdrs/ } \\
/ \text { dis//tupa/ } \\
/ \mathrm{dis} / / \mathrm{t} \supset \mathrm{fis} / \\
/ \mathrm{dis} / / \mathrm{t} \supset \mathrm{l} \partial / \\
/ \mathrm{dis} / / \mathrm{t} \supset \mathrm{mi} /\end{array}$ & $\begin{array}{l}\text { /gisti/ } \\
\text { /disti/ }\end{array}$ \\
\hline
\end{tabular}

TABEL 2: Gegewens omtrent die proefpersone

\begin{tabular}{|c|c|c|c|c|}
\hline Proefpersoon & Ouderdom & Geslag & $\begin{array}{c}\text { Suiwertoon- } \\
\text { drempels } \\
\text { dBL/dBR }\end{array}$ & Spreektaal \\
\hline 1 & 21 & Vroulik & $5 / 10$ & Afrikaans \\
\hline 2 & 19 & Vroulik & $10 / 10$ & Afrikaans \\
\hline 3 & 24 & Vroulik & $15 / 10$ & Afrikaans \\
\hline 4 & 24 & Manlik & $5 / 5$ & Afrikaans \\
\hline 5 & 20 & Manlik & $10 / 10$ & Afrikaans \\
\hline
\end{tabular}


geronde vokaal bevat nie. Die kontrole segmentreekse is soortgelyk aan die wat in die eksperimentele ondersoek in kombinasie met 'n geronde vokaal gebruik word en is ook telkens vyf maal herhaal. Indien hierdie betrokke segmentreekse nie tydens produksie met lipronding gepaard gaan nie, kan aanvaar word dat labiale EMGaktiwiteit wat voorkom in die toetsmateriaal wat wel 'n geronde vokaal bevat, verband hou met die geronde vokaal alleen (Figuur 2). Kontrolemateriaal sal telkens ná die eksperimentele materiaal beskryf word.

\section{Beskrywing van spraakmateriaal}

Spraakmateriaal om die invloed van die duur van die konsonantstring op die aanvang van labiale EMG aktiwiteit te bepaal

Die konsonantreekse wat in die studie gebruik word om die invloed van die duur van die konsonantstring (konsonantstringtyd) op die aanvangsmoment van labiale EMG-aktiwiteit (antisiperingstyd) te bepaal, is gekies n.a.v. 'n soortgelyke studie wat in Sweeds uitgevoer is (Lubker, 1981). Die geronde vokale is egter gekies n.a.v. Afrikaanse vokale wat in Afrikaans gespesifiseer is t.o.v. ronding.

Die kontrole en eksperimentele materiaal om die invloed van die duur van die konsonantstring op die aanvang van labiale EMG-aktiwiteit te bepaal, het bestaan uit onsin segmentreekse in die vorm: $/ \mathrm{V}_{1} \mathrm{~K}_{\mathrm{n}} \mathrm{V}_{2}$.

$V_{1}$ verwys na die hoë voorvokaal $/ \mathrm{i} /$ wat met'n gespreide lipposisie geproduseer word en dus nie sal inmeng met labiale ronding nie. $K_{n}$ verwys na die konsonantstring bestaande uit 1-5 nie-labiale konsonante en $V_{2}$ verwys in die geval van die kontrolemateriaal na die hoë voorvokaal /i/ en in die geval van die eksperimentele materiaal na die geronde vokaal $/ \mathrm{J} /$ of $/ \mathrm{u} /$. Twee geronde vokale is ingesluit ten einde die hoeveelheid data te vermeerder en te bepaal of die twee geronde vokale 'n ooreenstemmende effek het. Die spesifieke uitings wat vir die eksperimentele en kontrole materiaalgroepe gebruik is verskyn in Tabel 1.

Spraakmateriaal om die verloop van EMG-aktiwiteit te ondersoek vir uitings wat bestaan uit twee geronde vokale wat deur 'n nie-labiale konsonant geskei word $\left(\mathrm{V}_{8} K_{n i} V_{g}\right.$ konteks)

Die eksperimentele materiaal het telkens bestaan uit twee geronde vokale wat deur 'n nie-labiale konsonant geskei is. Om te kontroleer dat labiale EMG-akti witeit wel voorkom a.g.v. die voorkoms van die geronde vokaal en dat die konsonante $/ \mathrm{s} /$ en $/ \mathrm{k} /$ in die betrokke uitings nie met liprondingsaktiwiteit geproduseer word nie, is

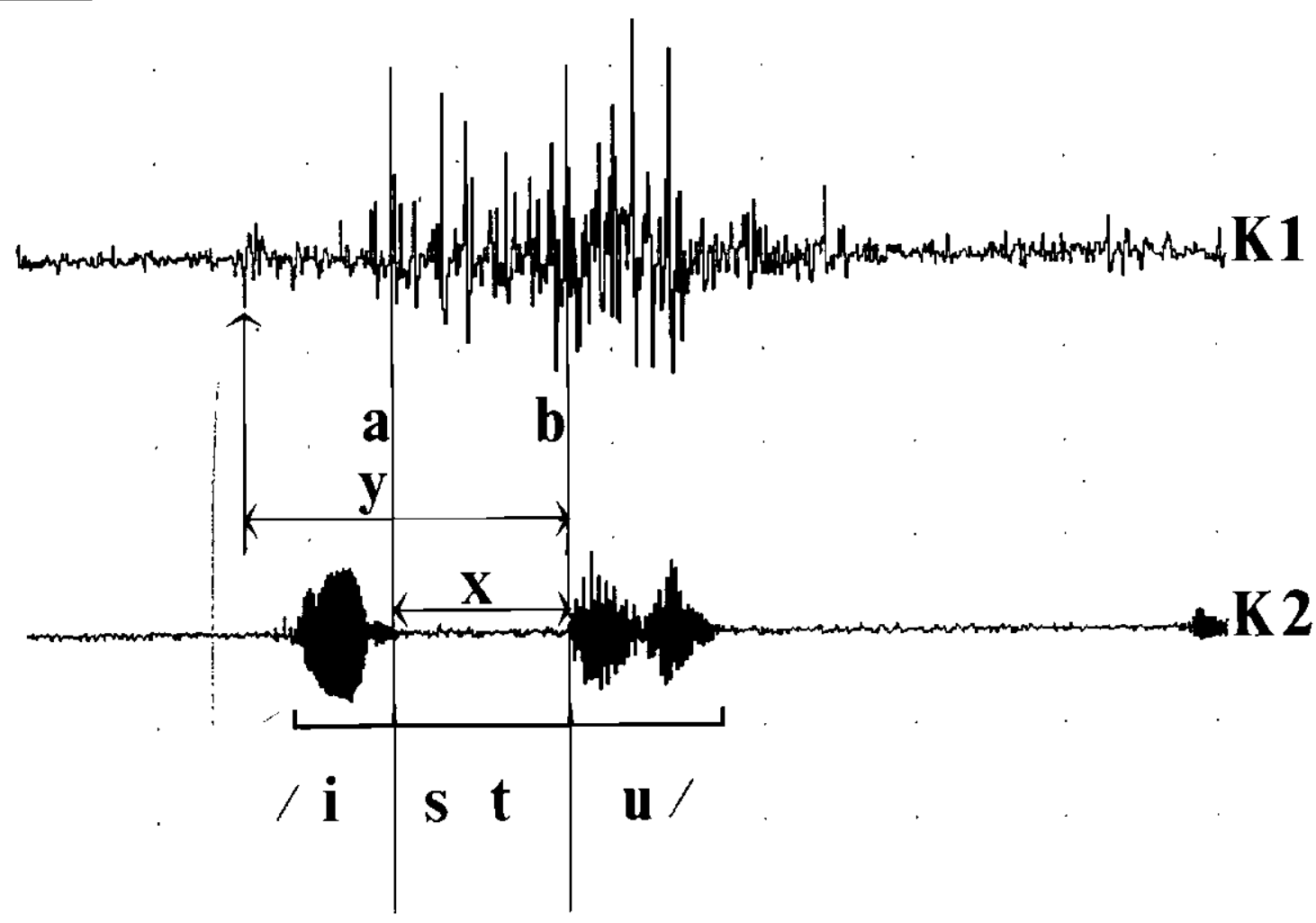

K1: Kanaal 1 - EMG aktiwiteit

K2: Kanaal 2 - Spraaksein

$\mathrm{x}$ : Konsonantstringtyd - die stemlose deel van die uiting

y: Antisiperingstyd - die afstand vanaf die aanvang van EMG-aktiwiteit tot die akoestiese aanset van die geronde vokaal

a: Kursor 1 - geplaas op die aanvang van die konsonantstring

b: Kursor 2 - geplaas op die akoestiese aanvang van die geronde vokaal

FIGUUR 1: Rekenaaruitdruk vanaf Medelec Mystro MS25 ter illustrasie van konsonantstringtyd, antisiperingstyd en optekenkanale. 
kontrole-uitings saamgestel. Die spesifieke uitings wat vir die eksperimentele en kontrole materiaalgroepe gebruik is verskyn in Tabel 1.

Spraakmateriaal om die invloed van woordgrense op die aanvang van labiale EMG aktiwiteit te bepaal

Uitings is saamgestel wat as een of twee woorde uitgespreek moes word. Die konsonantkombinasie/st/ het beide binne 'n woord en oor 'n woordgrens voorgekom (Benguerel \& Cowan, 1974). Die uitings is telkens met 'n nie-labiale konsonant begin sodat daar tydens produksie van die klank nie met lipronding ingemeng word nie. Uitings is telkens met die geronde vokaal / $/ \mathrm{en} / \mathrm{J} /$ opgestel ten einde die hoeveelheid data te vermeerder en te bepaal of die twee geronde vokale 'n ooreenstemmende effek het. Dit was egter moeilik om sinvolle uitings te vind wat aan die vereistes wat die metings stel voldoen. Daar is gepoog om veral die uitings wat as twee woorde uitgespreek moes word sinvol te hou. Twee van hierdie ses uitings was egter sinloos wat dus lei tot kunsmatige woordgrense. Hierdie feit sal egter by die interpretasie van die resultate in gedagte gehou word.

Om te bepaal of die rondingsbeweging oor die woordgrens voorgekom het, $m$.a.w. of die beweging alreeds gedurende die eerste woord geinisieer is, is gebruik gemaak van Groep B uitings, aangesien hierdie uitings as twee woorde uitgespreek is. Twee van die uitings met die vokaal $/ \mathrm{u} /$ was ongelukkig onsinuitings, terwyl die res van die uitings sinvolle woorde was. Daar kon dus so bepaal word of die rondingsbeweging oor die woordgrens van sinvolle én onsinuitings voorkom, of nie. Om te bepaal of die woordgrens die aanvang van ronding beduidend beïnvloed het vir uitings wat onderskeidelik as een en twee woorde uitgespreek is, waar die konsonantkombinasie /st/ onderskeidelik binne die woord en oor die woordgrens voorkom (Benguerel \& Cowan, 1974) is gebruik gemaak van Groep A en Groep B uitings.

\section{- Eksperimentele materiaal:}

\begin{tabular}{|c|c|c|c|}
\hline Groep A & $\begin{array}{l}\text { /gistul/ } \\
\text { /gistut/ } \\
\text { /gistup/ } \\
\text { /gist } \supset \text { f/ } \\
\text { /gist } \supset \text { // } \\
\text { /gist } \supset \mathrm{m} /\end{array}$ & Groep B & 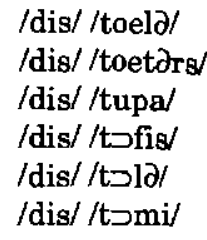 \\
\hline
\end{tabular}

\section{- Kontrole materiaal:}

Die kontrole-uitings is opgestel om te kontroleer dat die konsonante $/ g /, / d / / s /$ en $/ t /$ wat die geronde vokaal voorafgaan nie met lipronding geproduseer word nie. Die geronde vokaal wat in die toetsmateriaal voorgekom het, is vervang met die hoë voorvokaal/i/ wat met'n gespreide lipposisie geproduseer word en dus nie met lipronding sal inmeng nie. Die kontrole-uitings het dus bestaan uit die deel van die toetsmateriaal wat die geronde vokaal voorafgaan en die hoë voorvokaal /i/, omdat slegs hierdie dele van die uitings vir analise gebruik is.

Die kontrole uitings was soos volg:

/gisti/

/disti/

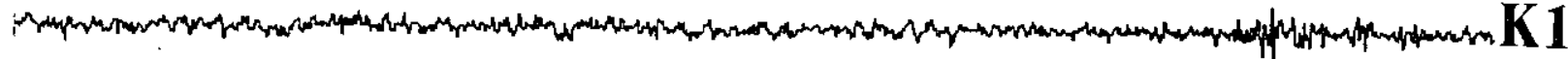

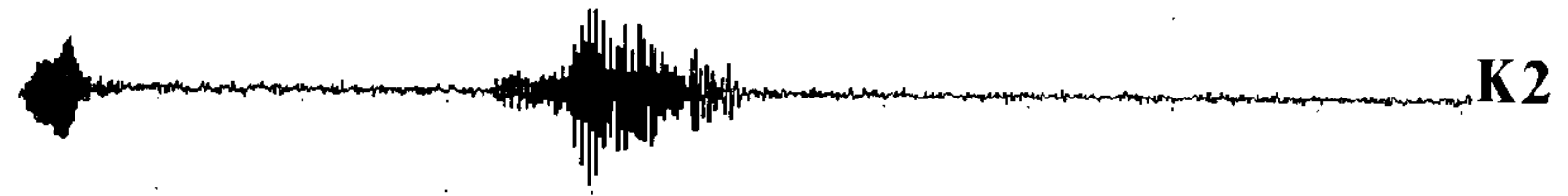

1

$/ \mathbf{i} \quad \mathbf{s} \quad \mathbf{t} \quad \mathbf{s} \quad \mathbf{i} /$

FIGUUR 2: Rekenaaruitdruk vanaf Medelec Mystro MS25 ter illustrasie van die afwesigheid van EMGaktiwiteit tydens die produksie van 'n kontrole-uiting 


\section{PROSEDURE VIR OPNAME}

Die navorser is bygestaan deur'n neuroloog wat ervare is in die uitvoering van elektromiografiese ondersoeke. 'n Bipolêre naaldelektrode is in die midlyn van die Musculus Orbicularis Oris, bekend as die agonis vir lipronding (BellBerti \& Harris, 1979) geplaas. Die elektromiografiese altiwiteit geassosieer met lipronding van die spier is op kanaal een van die elektromiograaf opgeneem. Die mikrofoon is op ' $n$ afstand van $5-10 \mathrm{~cm}$ vanaf die spreker se mond geplaas en die spraaksein is op kanaal twee van die elektromiograaf opgeteken. Die gemiddelde van die vyf produksies van elke uiting vir die elektromiografiese aktiwiteit en die visuele voorstelling van die spraaksein is onder mekaar op die ingeboude rekenaarskerm vertoon. 'n Grondelektrode op die persoon se linkerwang is gebruik om enige vreemde elektriese stroom te ontvang en gevolglike artefakte uit te skakel.

Die eksperimentele materiaal is op kaartjies van $10 \mathrm{x}$ $4 \mathrm{~cm}$ geskryf en die kaartjies is geskommel sodat eksperimentele materiaal wat dieselfde aspek toets nie ná mekaar voorgekom het nie. Hierdeur is gepoog om die moontlike invloed wat die woorde op mekaar kon hê uit te skakel. Die kontrole materiaal is eerste geproduseer en indien liprondingsaktiwiteit tydens die produksie van die kontrole materiaal teenwoordig was, is die persoon nie in die studie gebruik nie. Dit het wel gebeur dat een persoon as gevolg van hierdie rede nie by die studie ingesluit is nie. Die proefpersone is vooraf elkeen geleentheid gegee om die uitspraak van die uitinge te oefen.

\section{ANALISE VAN DATA}

Tydens analise van die resultate is elke persoon se data wat op 'n rekenaardisket gestoor is, herroep. Die elektromiografiese aktiwiteit op kanaal een en die spraaksein op kanaal twee vir die betrokke uiting het dan onder mekaar op die rekenaarskerm verskyn. Deur middel van twee kursors kon die navorser dan die tydsverloop tussen die verlangde punte meet. Soos die kursors beweeg is, het die tydsverskil tussen die twee kursors in millisekondes op die rekenaarskerm verskyn. Die amplitude van 'n sekere punt kon ook bepaal word d.m.v. die plasing van die kursor op daardie punt. Die amplitude in ${ }_{4} V$ vir 'n spesifieke plasing het ook onder aan die rekenaarskerm verskyn.

Analise van data om die invloed van die duur van die konsonantstring (konsonantstringtyd) op die aanvang van labiale EMG-aktiwiteit (antisiperingstyd) te bepaal

Vir elke uiting is die duur van die konsonantstring in millisekondes gemeet (konsonantstringtyd) deur die kursors op die begin en einde van die konsonantstring, m.a.w. die stemlose deel van die uiting te plaas. Die analise is uitgevoer op kanaal 2, m.a.w. die spraaksein.

Vervolgens is die tydsverloop in millisekondes bepaal vanaf die aanvang van EMG-aktiwiteit (kanaal 1) tot die akoestiese aanset van die geronde vokaal (kanaal 2) (antisiperingstyd). Die begin van EMG-aktiwiteit is beskou as die eerste duidelike uitwyking vanaf die basislyn soos beoordeel deur die navorser en die neuroloog (Figuur 1).

Die verband tussen antisiperingstyd en konsonantstringtyd is bepaal deur statistiese metodes soos by die verwerking van data beskryf word. Die oogmerk was dus om te bepaal of antisiperingstyd wissel na gelang die duur van die konsonantstring wissel.

\section{Analise van data om koartikulasie van een geronde vokaal na 'n ander te ondersoek $\left(V_{g} K_{n l} V_{g}\right.$-konteks)}

By die analise van die data is die verloop van die EMGaktiwiteit nagegaan. Daar is gekyk of daar twee piekperiodes voorkom met ' $n$ duidelike afname in aktiwiteit tussen die twee piekperiodes. Indien twee piekperiodes onderskei kan word, is die maksimum amplitude in mikrovolt van die twee piekperiodes gemeet d.m.v. die kursors op die rekenaarskerm. Soos die kursors beweeg is, het die amplitude in mikrovolt aan die onderkant van die skerm verskyn. Die minimum amplitude van die keep tussen die twee piekperiodes is ook bepaal. Die verloop van die EMG-aktiwiteit is subjektief beoordeel deur die navorser en die neuroloog.

Analise van data om die invloed van woordgrense op die aanvang van labiale EMG-aktiwiteit te bepaal

Die materiaal is só opgestel dat die konsonante wat die geronde vokaal voorafgaan stemloos is en dus maklik onderskeibaar is van die stemhebbende geronde vokaal op die visuele voorstelling van die spraaksein.

Die duur van die konsonantstring in millisekondes is bepaal asook die tydsverloop vanaf die aanvang van EMGaktiwiteit tot die aanvang van die geronde vokaal. Bogenoemde is gemeet vir beide Groep A (uitings wat as een woord uitgespreek is) en Groep B (uitings wat as twee woorde uitgespreek is).

\section{VERWERKING VAN DATA}

\section{VERWERKING VAN DATA OM DIE INVLOED VAN DIE DUUR VAN DIE KONSONANTSTRING (KONSONANT STRINGTYD) OP DIE AANVANG VAN LABIALE EMG- AKTIWITEIT (ANTISIPERINGSTYD) TE BEPAAL}

Puntediagramme is afsonderlik vir elke proefpersoon vir eksperimentele groep 1 en groep 2 uitings onderskeidelik, opgestel. $\mathrm{Na}$ gelang van die data is daar onderskeidelik van lineêre en paraboliese passings gebruik gemaak, waar daar van die kleinstevierkantmetode gebruik gemaak is. Vir die lineêre en paraboliese passings is die akkuraatheid van die passing weergegee deur die simbole $r$ en $R$ onderskeidelik, waar die terme telkens die fraksie van akkuraatheid voorstel ( $r$ of $R=1$ stel dus ' $n$ perfekte passing voor). 'n Akkurate lineêre passing impliseer dat $y$ toeneem, namate $x$ toeneem. Dit sou dus beteken dat antisiperingstyd toeneem na gelang konsonantstringtyd toeneem. 'n Akkurate paraboliese passing impliseer dat y toeneem tot op 'n punt en daarna afneem, ten spyte van'n toename in $x$. Dit sou dus beteken dat antisiperingstyd 'n maksimum bereik, waarna dit nie verder toeneem nie.

\section{VERWERKING VAN DATA OM DIE INVLOED VAN WOORDGRENSE OP. DIE AANVANG VAN LABLALE EMG-AKTTWITEIT TE BEPAAL}

Indien antisiperende labiale koartikulasie oor die woordgrens strek sal antisiperingstyd (y) groter wees as konsonantstringtyd (x) (Figuur 3). 'n Gepaarde t-toets 
(eensteekproefgeval) is m.b.v. PROC UNIVARIATE en SAS uitgevoer om te bepaal of daar' $n$ beduidende grootteverskil tussen die waardes van $x$ en $y$ is. Met behulp van die toets is 'n p-waarde verkry, en indien die waarde kleiner as 0,05 is, dui dit op 'n beduidende grootteverskil. 'n Vyf persent peil van betekenis vir betekenisvolheid is dus gehandhaaf. 'n Beduidende grootteverskil sou daarop dui dat antisiperende labiale koartikulasie al gedurende die eerste uiting van twee uitinge voorgekom het. In hierdie geval het antisiperende labiale koartikulasie dus wel oor die woordgrens voorgekom.

Vervolgens is bepaal of daar ' $n$ beduidende verskil is tussen die antisiperingstye van uitinge waarin die konsonantkombinasie /st/ binne 'n woord voorkom en vir uitinge waar die spesifieke konsonantkombinasie geskei word deur 'n woordgrens. Daar moet dus bepaal word of EMG-aktiwiteit telkens min of meer op dieselfde punt in die woord 'n aanvang neem, vir uitings wat as een en twee woorde uitgespreek word. Die verskil tussen $x$ en $y$ is bereken vir beide die uitings wat as een en twee woorde uitgespreek is. Die rede waarom die verskil bereken is, is ten einde te kompenseer vir die verskil in konsonantstringtyd van die twee groepe uitings.

Die verkrygde waardes word dan m.b.v. 'n gepaarde ttoets (eensteekproefgeval) geëvalueer ten einde te bepaal of daar ' $n$ beduidende verskil in antisiperingstyd tussen die twee groepe uitings bestaan. Met behulp van die toets is 'n p-waarde verkry en indien die waarde dus groter as 0,05 is, is die verskil nie beduidend nie. 'n Vyf persent peil van betekenis vir betekenisvolheid is weer gehandhaaf. Indien die verskil nie beduidend is nie, impliseer dit dat die woordgrens in hierdie konteks nie die aanvangsmoment van labiale rondingsaktiwiteit beïnvloed nie. Antisipering begin dus op dieselfde plek in die uitings, ongeag of die uiting as een of twee woorde uitgespreek is.

\section{BESKRYWING VAN RESULTATE}

\section{BEPALING VAN DIE TEMPORALE OMVANG VAN ANTISIPERENDE LABIALE KOARTIKULASIE}

Die resultate van die verskillende proefpersone en segmentreekse met die geronde vokaal $/ \omega /$ en $/ /$ word opsommender wys bespreek aangesien, daar konstant sekere tendense teenwoordig was. Soos reeds genoem by die verwerking van data is daar telkens bepaal of 'n lineêre of paraboliese verband tussen $x$ en $y$ bestaan, waar die $x$ as telkens die duur van die konsonantstring in millisekondes aandui (konsonantstringtyd), en die y-as telkens na die tydsverloop vanaf die aanvang van EMG-aktiwiteit tot die akoestiese aanset van die geronde vokaal (antisiperingstyd), ook in millisekondes, verwys. Ter illustrasie van die paraboliese en lineêre verband tussen $x$ en $y$ word slegs figure 4 en 5 ingesluit, aangesien die resultate van die ander proefpersone deurgaans dieselfde tendens (paraboliese of lineêre verband) getoon het. Die roudata wat antisiperingstyd en konsonantstringtyd vir elke uiting en proefpersoon toon verskyn in Bylae 1 .

'n Paraboliese verband tussen $x$ en y is twee keer verkry vir uitings van ekperimentele materiaalgroep 1 en een keer vir uitings van eksperimentele materiaalgroep 2. Figuur 4 illustreer die resultate van proefpersoon 1 m.b.t. eksperimentele materiaalgroep 1 waar 'n paraboliese verband tussen $x$ en $y$ bestaan. ' $n$ Paraboliese verband impliseer dat antisiperingstyd toegeneem het namate konsonantstringtyd toegeneem het, totdat laasgenoemde 'n maksimum bereik (in hierdie geval $524 \mathrm{~ms}$ ), waarna antisiperingstyd weer afgeneem het.

'n Lineêre verband tussen $x$ en $y$ is verkry in twee gevalle van eksperimentele materiaal groep 1 uitings en in drie gevalle van eksperimentele materiaalgroep 2

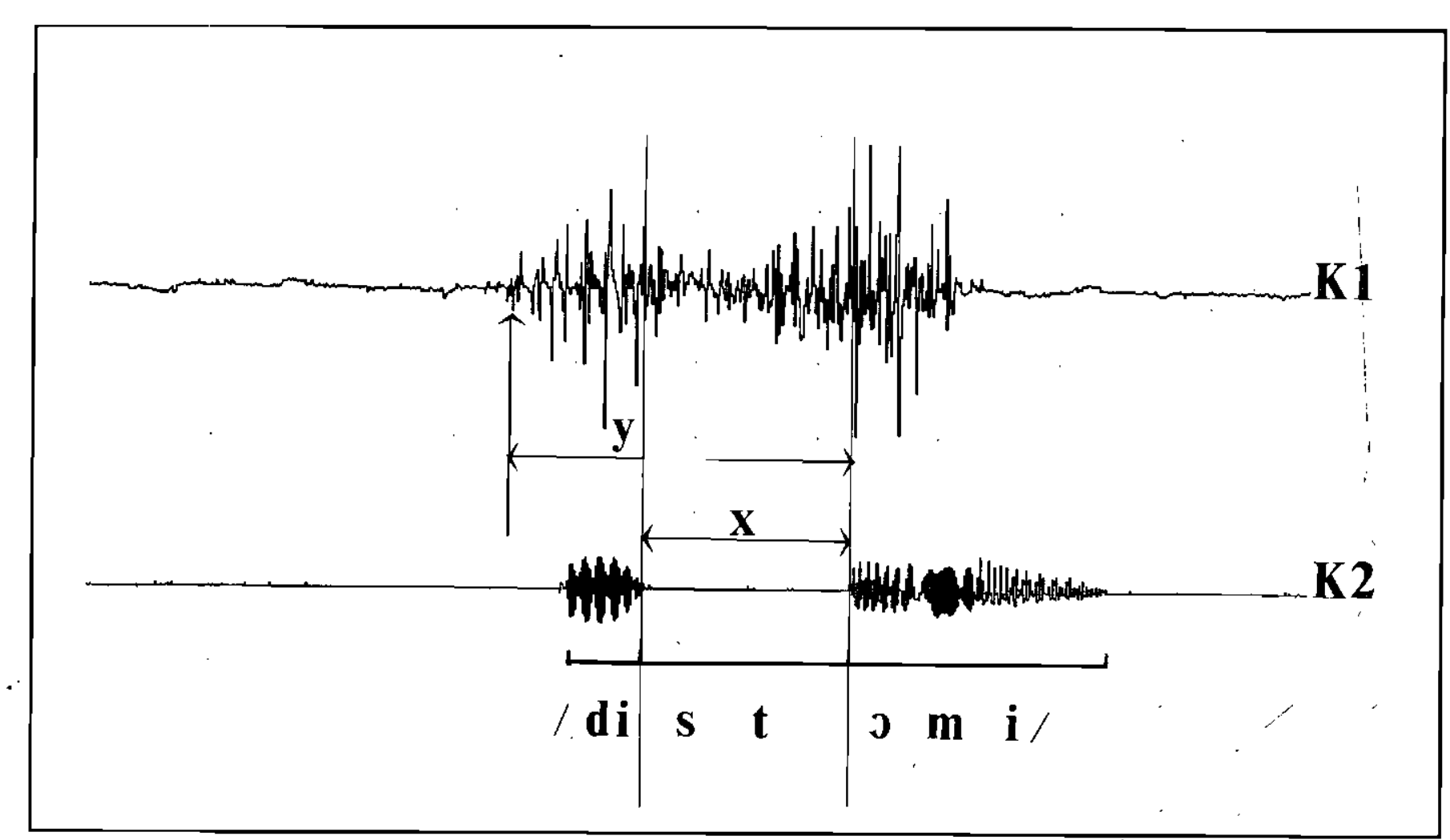

FIGUUR 3: Rekenaaruitdruk vanaf Medelec Mystro MS25 ter illustrasie van die voorkoms van antisiperende labiale koartikulasie oor 'n woordgrens 
uitings. Figuur 5 illustreer die resultate van proefpersoon 1 , waar'n positiewe lineêre verband tussen $x$ en y verkry is vir eksperimentele materiaalgroep 2.'n Positiewe lineêre verband impliseer dat namate konsonantstringtyd $(x)$ toegeneem het, antisiperingstyd $(y)$ ook toegeneem het.

In twee gevalle (eksperimentele materiaalgroep 2 van proefpersoon 2 en eksperimentele materiaalgroep 1 van proefpersoon 4) kon daar nie 'n paraboliese of lineêre verband tussen $x$ en $y$ verkry word nie, maar met beskouing van die data is in beide die gevalle gevind dat antisiperingstyd wel toegeneem het, namate konsonantstringtyd toegeneem het tot op 'n sekere punt.

Alhoewel dit uit die resultate blyk dat die antisiperingstye van die verskillende proefpersone vir dieselfde uitings verskil, toon al die proefpersone se

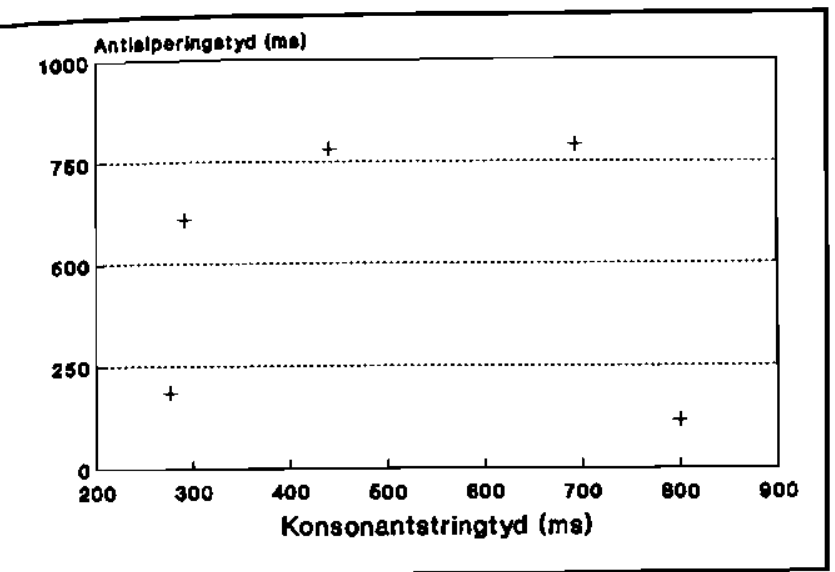

FIGUUR 4: Puntediagram van konsonantstring teenoor antisiperingstyd van eksperimentele materiaalgroep 1 vir proefpersoon 1. resultate egter dat antisiperingstyd toeneem namate konsonantstringtyd toeneem. Aangesien die verskynsel voorgekom het tydens die uitinge met die geronde vokaal $/ /$ en / $/ \mathrm{d}$ / kan afgelei word dat die twee vokale 'n ooreenstemmende effek het. Antisiperingstyd het gewissel vanaf $144 \mathrm{~ms}$ vir die uiting /is $د /$ (by proefpersoon 2) tot $950 \mathrm{~ms}$ vir die uiting /ikststu/ (by proefpersoon 3 ). Al die proefpersone se antisiperingstye het vir eksperimentele materiaalgroep 2 egter 'n maksimum bereik en afgesien van'n toename in konsonantstringtyd het antisiperingstyd na hierdie punt nie verder toegeneem nie. Vir eksperimentele materiaalgroep 1 het slegs proefpersone een, twee en vyf se antisiperingstye 'n maksimum bereik. Die maksimum antisiperingstye van die verskillende proefpersone het ook verskil.

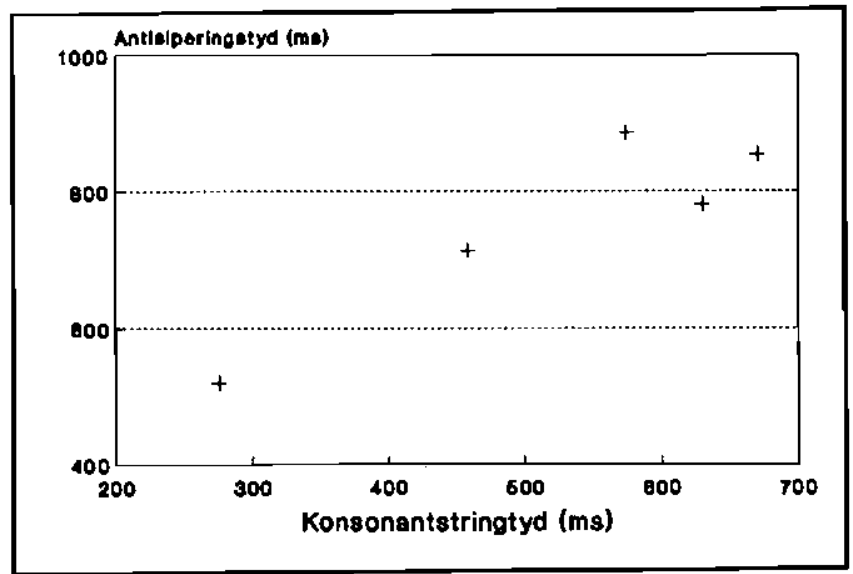

FIGUUR 5: Puntediagram van konsonantstringtyd teenoor antisiperingstyd van eksperimentele materiaalgroep 2 vir proefpersoon 1 .

TABEL 3: Gegewens aangaande verloop van EMG-aktiwiteit in die $V_{d} K_{n l} V_{g}$-konteks.

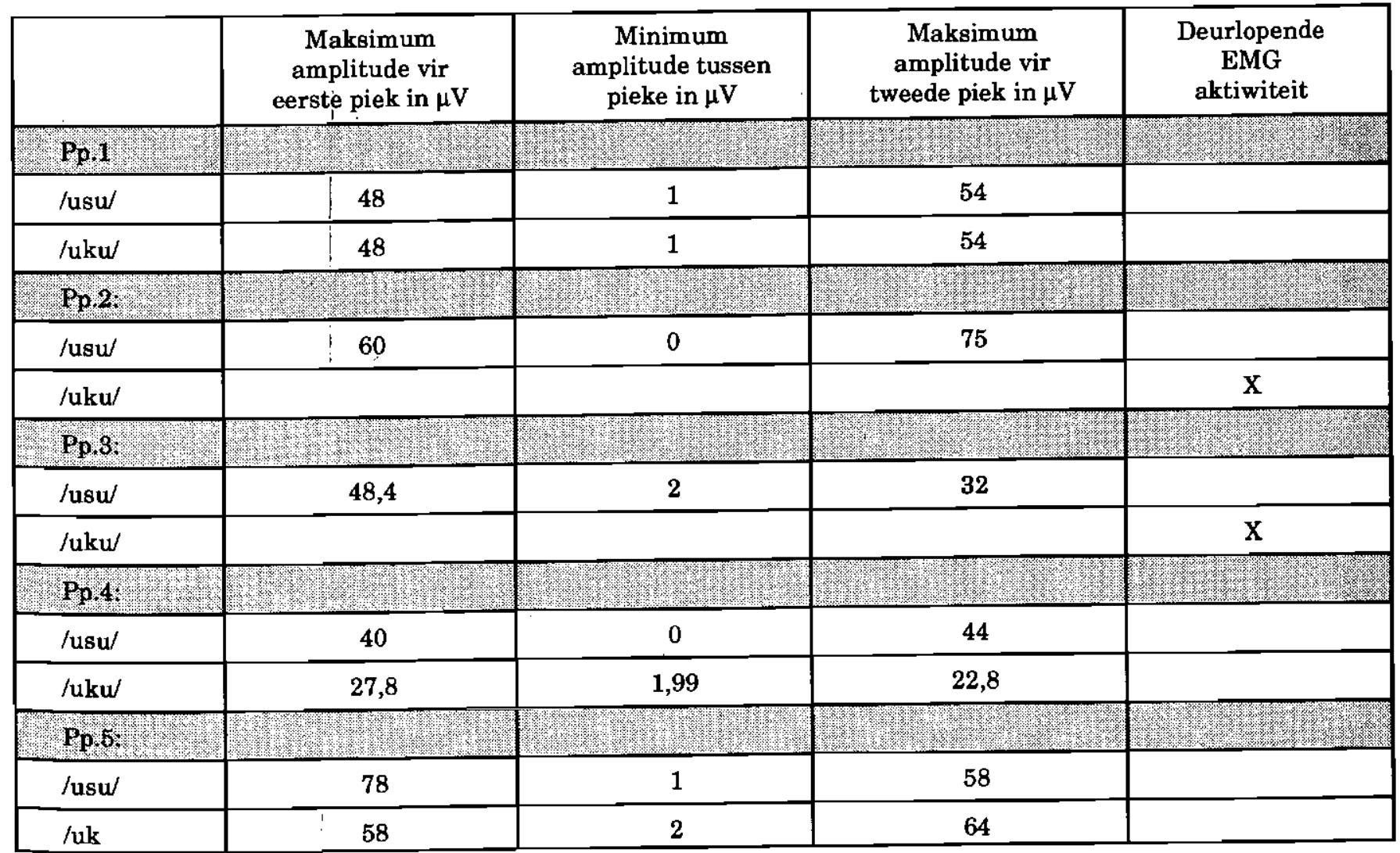




\section{BEPALING VAN DIE VERLOOP VAN LABIALE EMG- AKTIWITEIT IN DIE $V_{q} K_{n l} V_{g}$-KONTEKS}

Ter illustrasie van hierdie resultate word Tabel 3 ingesluit. Daar word telkens in mikrovolt aangedui wat die maksimum amplitude van die twee piekperiodes was, indien teenwoordig. Verder word die minimum amplitude van die EMG-aktiwiteit tussen die twee piekperiodes ook in mikrovolt aangedui. In die tabel word aangetoon dat deurlopende EMG-aktiwiteit voorgekom het indien geen prominente pieke met' $n$ afname in EMG-aktiwiteit tussen die pieke onderskei kon word tydens beoordeling deur die neuroloog en navorser nie.

Uit die resultate blyk dit dus dat die keepverskynsel by agt uit die tien uitings voorgekom het. Daar is egter slegs van een intervokaliese konsonant gebruik gemaak en die konsonantstringtyd was dalk in die twee gevalle waar die keepverskynsel nie waargeneem is nie, korter as die tyd wat nodig is vir die spieraktiwiteit om te daal tot die basislyn vir die eerste / $\mathbf{w}$ / en dan weer te styg vir die tweede /u/ (Bell-Berti \& Harris, 1982). Daar word aanbeveel dat die verskynsel in die toekoms ondersoek word vir uitings waar meer as een intervokaliese konsonant gebruik word, om te bepaal of die keepverskynsel konstant voorkom.

\section{BEPALING VAN DIE EFFEK VAN WOORDGRENSE OP DIE AANVANG VAN LABIALE EMG-AKTIWITEIT}

Tydens statistiese verwerking is die roudata van al die proefpersone vir eksperimentele materiaalgroep $A$ en eksperimentele materiaalgroep $B$ uitings gesamentlik verwerk. Om te bepaal of antisiperende labiale koartikulasie oor woordgrense voorkom, is soos reeds genoem, gebruik gemaak van 'n gepaarde t-toets om te bepaal of die antisiperingstyd (y) groter is as konsonantstringtyd $(x)$. Indien $p<0,05$ dan is $y>x$. Daar is gevind dat $\mathbf{p}$ gelyk is aan 0.0001 en dus is $\mathbf{y}$ groter as $\mathbf{x}$. Die resultate impliseer dat antisiperende labiale koartikulasie telkens reeds gedurende die produksie van die eerste woord voorgekom het en wel voor die produksie van die laaste segment van die eerste woord. Die voorkoms van die woordgrens het dus nie die voorkoms van antisiperende labiale koartikulasie gedurende die eerste woord oor die woordgrens geïnhibeer nie. Die verskynsel het konstant by al die proefpersone voorgekom vir die sinvolle en onsinuitinge.

Vervolgens is bepaal of daar ' $n$ beduidende verskil is tussen die antisiperingstye van uitinge warin die konsonantkombinasie /st/ binne 'n woord voorkom en uitinge waar $/ \mathrm{s} / \mathrm{en} / \mathrm{t} /$ geskei word deur'n woordgrens. Weer eens is die data van al die proefpersone gesamentlik verwerk. Die p-waarde wat $m$.b.v. die t-toets verkry is, is 0,7982 . Aangesien die waarde groter as 0,05 is, dui dit daarop dat daar nie 'n beduidende verskil is tussen die antisiperingstye van die uitings wat as een of twee woorde uitgespreek is nie. Antisipering begin dus op ongeveer dieselfde foneem voor die geronde vokaal, ongeag of die uiting uit een of twee uitings bestaan. Die resultaat impliseer dat in twee uitings soos /gistul/ en /dis//tul / antisipering in albei gevalle bv. by die / i/ sal begin. Die teenwoordigheid van 'n woordgrens beïnvloed dus nie die aanvang van antisipering nie. Die verskynsel het konstant by al die proefpersone voorgekom.

\section{BESPREKING VAN RESULTATE}

\section{DIE TEMPORALE OMVANG VAN ANTISIPERENDE LABIALE KOARTIKULASIE}

Die data van die huidige studie dui aan dat die aanvangsmoment van labiale EMG-aktiwiteit (antisiperingstyd) wissel, na gelang die duur van die konsonantstring wat die geronde vokaal voorafgaan wissel. Daar is gevind dat liprondingsaktiwiteit toenemend vroeër 'n aanvang neem, namate die duur van die voorafgaande konsonantstring toeneem. Die antisiperingstye het gewissel vanaf $144 \mathrm{~ms}$ (proefpersoon 4) vir die uiting /isu/ tot $950 \mathrm{~ms}$ (proefpersoon 3) vir die uiting /ikststu/. Alhoewel die verskillende proefpersone se antisiperingstye vir dieselfde uitings verskil het, het almal se resultate getoon dat antisiperingstyd toeneem, namate konsonantstringtyd toeneem. In sommige gevalle (proefpersone een, twee, drie en vier) het dit voorgekom of van die proefpersone hul maksimum antisiperingstyd behaal het, aangesien daar op 'n sekere punt 'n afname in antisiperingstyd was, ten spyte van 'n toename in konsonantstringtyd.

Die feit dat antisiperingstyd in sommige gevalle op 'n sekere punt nie verder toegeneem het nie, ten spyte van 'n toename in konsonantstringtyd, kan dui op'n moontlike temporale beperking vir antisiperende labiale koartikulasie. In die huidige studie verskil die maksimum temporale omvang wat behaal is van persoon tot persoon. Die maksimum antisiperingstyd wat'n persoon behaal het weerspieël dus moontlik die maksimum grootte van die beplanningseenhede wat die persoon gebruik in die motoriese beplanning van sy spraak, van watter aard die eenhede ook al mag wees.

Die bevindings aangaande die temporale omvang van antisiperende labiale koartikulasie kan gebruik word om sekere afleidings te maak aangaande die wyse waarop motoriese beplanning van spraak deur die brein geskied. Die resultate van die huidige studie is in ooreenstemming met bevindings van ondersoekers wat meen dat antisiperende labiale koartikulasie 'n wye omvang kan hê (Daniloff \& Moll, 1968; Benguerel \& Cowan, 1974; McAllister et al., 1974). Die sterk positiewe verband tussen die duur van die nie-labiale konsonantstring en die aanvangsmoment van labiale EMG-aktiwiteit, ondersteun die hipotese dat die aanvang van labiale ronding beplan word in verhouding tot die temporale omvang van die nielabiale konsonantstring wat die geronde vokaal voorafgaan. Daar kan na aanleiding hiervan geredeneer word dat die brein soveel as bv. $950 \mathrm{~ms}$ (by proefpersoon 3) vooraf besef dat 'n geronde vokaal geproduseer gaan word. Verder kom dit voor asof die brein ook bewus is van die feit dat daar geen aktiwiteit van die lippe vereis word in die intervokaliese periode nie, aangesien die konsonantstring nie-labiaal is. As gevolg hiervan kan vroeë lipronding geïnisieer word. Die resultaat lewer dus bewys van die voorafbeplanning van spraak deur die brein en impliseer dat antisiperende labiale koartikulasie 'n bespiedingsmeganisme vir spraakproduksie reflekteer (Lubker \& Gay, 1982). Hierdie bevindings is dus in teenstelling met studies waar bevind is dat die aanvang van die rondingsbeweging temporaal gebonde is aan die akoestiese aanset van die geronde vokaal en nie beïnvloed word deur die duur van die voorafgaande konsonantstring nie (Bell-Berti \& Harris, 1979;1982; Gay, 1979).

'n Moontlike verklaring vir die opponerende resultate 
van die huidige studie teenoor diè van Bell-Berti en Harris $(1979 ; 1982)$ kan wees dat in die spraakmateriaal wat deur Bell-Berti en Harris (1982) gebruik is, die konsonantstringtyd nooit $420 \mathrm{~ms}$ oorskry het nie en 'n maksimum van vier intervokaliese konsonante gebruik is. Antisiperingstyd sou dus moeilik die duur van $420 \mathrm{~ms}$ oorskry. Verder was antisiperingstyd soms in genoemde navorsers se studie wel $300 \mathrm{~ms}$ en $400 \mathrm{~ms}$ soos blyk uit hul studie se puntediagramme. Antisiperingstyd was dus nie konstant $250 \mathrm{~ms}$ (Bell-Berti \& Harris, 1982) nie.

Die omvang van antisiperende labiale koartikulasie kan ook gebruik word om modelle van spraakproduksie, wat poog om o.a. die verskynsel van antisiperende koartikulasie te verklaar, te ondersoek. Kozhevnikov en Chistovich (in Kent \& Minifie, 1977) postuleer dat die omvang van antisiperende koartikulasie die grootte van die eenheid wat in die beplanning van spraak gebruik word, reflekteer. $\mathrm{Na}$ aanleiding van hulle resultate met Russiese proefpersone, het hulle waargeneem dat lipprotrusie vir konsonantkombinasies wat geronde vokale voorafgaan, begin met die eerste konsonant in die reeks. Die navorsers het tot die gevolgtrekking gekom dat artikulatoriese bewegings georganiseer word in lettergrepe met die vorm van $\mathrm{KV}, \mathrm{KKV}, \mathrm{KKKV}$ ens. Die lettergreep kan dus bestaan uit enige hoeveelheid konsonante, gevolg deur 'n vokaal. Die basiese hipotese wat deur die Kozhevnikov-Chistovich teorie (in Kent \& Minifie, 1977) gepostuleer word, is dat die motoriese beplanning van spraak onderbreek word by sekere intervalle, naamlik ná die produksie van 'n vokaal. Nadat 'n vokaal teëgekom is, begin' $n$ nuwe beplanningseenheid. Na aanleiding van hul bevindings het hulle' $n$ model, bekend as die artikulatoriese lettergreepmodel, gepostuleer wat poog om die verskynsel van antisiperende koartikulasie te verklaar.

Uit die resultate van die huidige studie blyk dit egter dat die rondingsbeweging in sommige gevalle alreeds voor of gedurende die eerste vokaal in die uiting 'n aanvang neem. Die rondingsbeweging word dus alreeds voor die produksie van die eerste konsonant in die uiting geïnisieer. Die verspreiding van die rondingsbeweging tot die vokaal wat die eerste konsonant in die reeks voorafgaan, is in ooreenstemming met die bevindings van Sussman en Westbury (1981), Benguerel en Cowan (1974) en Lubker (1981). Die arikulatoriese lettergreep, bestaande uit 'n sekere hoeveelheid konsonante wat deur'n vokaal gevolg word, kan dus nie as die enigste basiese invoereenheid vir die motoriese beplanning van spraak aanvaar word nie. Indien die omvang van antisiperende koartikulasie gebruik word as bewys van!die grootte en aard van die beplanningseenhede van artikulasie, dan is lettergrepe in die vorm $\mathrm{KV}$ of selfs $(\mathrm{K})^{\mathrm{n} V}$ (dit is enige hoeveelheid konsonante wat die geronde vokaal voorafgaan) nie die enigste moontlike invoereenhede nie (Kent \& Minifie, 1977). Die artikulatoriese lettergreep model van Kozhevnikov en Chistovich (in Kent \& Minifie, 1977) word dus nie n.a.v. die resultate van die huidige studie ondersteun nie.

Nog 'n model soos gepostuleer deur Henke'(in Kent \& Minifie, 1977) hipotetiseer dat die invoereenheid wat vir die motoriese beplanning van spraak gebruik word, uit groepe kenmerke bestaan. Henke (in Kent \& Minifie, 1977) postuleer dat elke foneem in 'n artikulatoriese reeks uit'n groep artikulatoriese kenmerke bestaan. Elke foneem het vir ' $n$ bepaalde kenmerk ' $n$ waarde van nul, plus, of minus. Wanneer 'n spreker 'n artikulatoriese reeks moet produseer, voer die brein 'n bespiedingsproses uit op die foneemstring. As ' $n$ bepaalde foneem 'n plus waarde het t.o.v. 'n spesifieke kenmerk by. ronding, en die segmente wat dit voorafgaan almal 'n nul- waarde het vir hierdie kenmerk, sal die kenmerk tydens produksie van die tussenkomende foneme geantisipeer word. Die voorafgaande foneme sal dus die kenmerkwaarde van die komende foneem aanneem. Hierdie beginsel geld slegs as die kenmerk nie onverenigbaar is met die kenmerke van die tussenkomende segmente nie, en staan bekend as Henke se "compatibility notion" (Kent \& Minifie, 1977:124).

Uit die huidige resultate blyk dit dat die rondingskenmerk wel tydens die produksie van die voorafgaande konsonantstring wat 'n nul waarde m.b.t. die rondingskenmerk het, geantisipeer is. Die rondingskenmerk is egter in sommige gevalle reeds deur die eerste vokaal in die reeks (/i/) aangeneem. Die vokaal /i/ het egter 'n negatiewe waarde vir die rondingskenmerk. Die feit dat labiale EMG-aktiwiteit alreeds gedurende die /i/ waargeneem is, is dus ' $n$ onverwagte resultaat indien die wyse van spraakbeplanning wat deur Henke (in Kent \& Minifie, 1977) voorgestel is, aanvaar word.

Die bevinding dat labiale EMG-aktiwiteit alreeds gedurende die /i/ voorkom, is in ooreenstemming met die bevindings van ander navorsers soos Benguerel en Cowan (1974), Lubker (1981) en Sussman en Westbury (1981). Aangesien die kontrole uitinge nie ronding vertoon nie, kan aanvaar word dat die resultaat nie die gevolg van 'n artefak in die meting is nie. 'n Moontlike verklaring vir die resultaat is voorgestel deur Sussman en Westbury (1981). Hierdie navorsers aanvaar ook 'n bespiedingsmeganisme wat in die motoriese beplanning van spraak deur die brein gebruik word, maar volgens hulle siening noodsaak die vokaal wat die geronde vokaal voorafgaan dat daar aanpassings gemaak moet word. Indien die voorafgaande vokaal biomeganies neutraal is t.o.v. lipronding, dan behandel die bespieder die segment as nog 'n neutrale segment in die reeks. As die voorafgaande vokaal antagonisties is t.o.v. ronding dan word temporale anpassings geïnkorporeer in die antisiperende rondingsbeweging, $m$.a.w. ronding begin vroeër as wanneer 'n neutrale vokaal teenwoordig is.

\section{DIE VERLOOP VAN LABIALE EMG-AKTIWITEIT IN 'N V $K_{n l} V_{i g}-K O N T E K S$}

Antisiperende labiale koartikulasie blyk afwesig te wees in reekse wat gespesifiseer word as geronde vokaal $\left(V_{o}\right)$ nie-labiale konsonant $\left(\mathrm{K}_{\mathrm{nl}}\right)$-geronde vokaal $\left(\mathrm{V}_{\mathrm{B}}\right)$. In die huidige studie is in agt van die tien uitings, twee temporaal onderskeibare pieke van Musculus Orbicularis Oris aktiwiteit gevind, en nie oordrag van die labiale EMGaktiwiteit vanaf die eerste geronde vokaal oor die konsonantstring wat neutraal is t.o.v. ronding na die tweede geronde vokaal nie (Figuur 14). Die bevindings stem ooreen met die bevindings van Gay (1979).

Navorsers wat meen dat antisiperende labiale koartikulasie tydsgebonde is aan die geronde vokaal meen dat die keep- of dubbele piek verskynsel (Lubker \& Gay, 1982) bewys lewer vir die werking van 'n tydsgebonde meganisme in die motoriese beplanning van spraak (Gay, 1979). Die navorsers daarenteen wat meen dat antisiperende labiale koartikulasie 'n wye omvang kan hê, meen egter dat die verskynsel slegs die noodsaaklikheid 
van idiosinkratiese aanpassings in beplanning, n.a.v. die aard van die eerste vokaal in die uiting, weerspieël (Sussman \& Westbury, 1981).

Die keepverskynsel word ook gebruik om reedsgenoemde spraakproduksiemodelle te ondersoek. Die verskynsel kan nie verklaar word as die bespiedingsmeganisme soos deur Henke (in Kent \& Minifie, 1977) gepostuleer, aanvaar word nie. Volgens Henke se model moes ronding ook gedurende die intervokaliese konsonant voorgekom het, aangesien die nie-labiale konsonant. neutraal is t.o.v. die rondingskenmerk. Dit lyk dus of die bespiedingsmeganisme in hierdie besondere geval nalaat om sy bespiedingsproses uit te voer. Geen antisiperende labiale koartikulasie vind in die konteks plaas nie.

Die feit dat geen antisiperende koartikulasie in die konteks plaasvind nie, opponeer verder die aanname van $(\mathrm{K})^{\mathrm{n}} \mathrm{V}$-eenhede as die basiese invoereenheid vir beplanning van spraak, soos gepostuleer deur Kozhevnikov en Chistovich (in Kent \& Minifie, 1977), omdat volgens die navorsers labiale EMG-aktiwiteit gedurende die eerste konsonant in die uiting ' $n$ aanvang moes neem en volgehou word oor die vokaal. Dit sou wees omdat hierdie navorsers invoereenhede in die vorm van $(K)^{\mathrm{n}} \mathrm{V}$ aanvaar as die basiese invoereenheid in die motoriese beplanning van spraak. Rondingsaktiwiteit het egter nie gedurende die konsonant voorgekom nie, soos blyk uit die resultate.

Die keepverskynsel het nie konstant voorgekom nie (in twee van die tien uitings afwesig) en is moontlik nie in genoeg diepte in die huidige studie ondersoek nie. Daar is vir toetsing van die keepverskynsel gebruik gemaak van uitinge wat slegs een intervokaliese konsonant bevat in die $\mathrm{V}_{\mathrm{g}} \mathrm{K}_{\mathrm{nl}} \mathrm{V}_{\mathrm{g}}$-konteks. Dit word aanbeveel dat die verskynsel in die toekoms in meer diepte ondersoek word deur gebruik te maak van uitinge wat langer intervokaliese konsonantstringe bevat.

\section{DIE EFFEK VAN WOORDGRENSE OP DIE AAN. VANG VAN LABLALE EMG-AKTTWITEIT}

In die huidige studie is gevind dat koartikulasie oor woordgrense kan voorkom. Verder is gevind dat vir uitinge waar'n konsonantkombinasie/st/ binne 'n woord en oor 'n woordgrens voorkom; die aanvangsmoment van ronding nie beduidend deur die woordgrens beïnvloed word nie. Die resultaat het vir beide die onsinvolle en sinvolle uitings wat as twee woorde uitgespreek is, gegeld. Die resultate wat toon dat die woordgrens nie 'n beduidende effek op die aanvang van ronding het nie, is in ooreenstemming met die bevindings van Daniloff en Moll (1968), Benguerel en Cowan (1974) en Bell-Berti en Harris (1982).

Die feit dat antisiperende labiale koartikulasie oor 'n woordgrens kan strek ondersteun die aanname van Van der Merwe (1986) dat die linguisties-simboliese beplanning en die motoriese beplanning van spraak deur die brein afsonderlik geskied. Die brein skei dus moontlik taal en motoriek tydens die motoriese beplanning van spraak.

Die onbeduidende effek van die woordgrens op die aanvang van labiale EMG-aktiwiteit is ook in stryd met die aanname van 'n artikulatoriese lettergreep met die formaat $(\mathrm{K})^{\mathrm{n}} \mathrm{V}$ as die basiese invoereenheid wat in die motoriese beplanning van spraak gebruik word. In die huidige studie is daar in 'n uiting soos $/ \mathrm{dis} / \mathrm{t} \mathrm{mi} /$ gevind

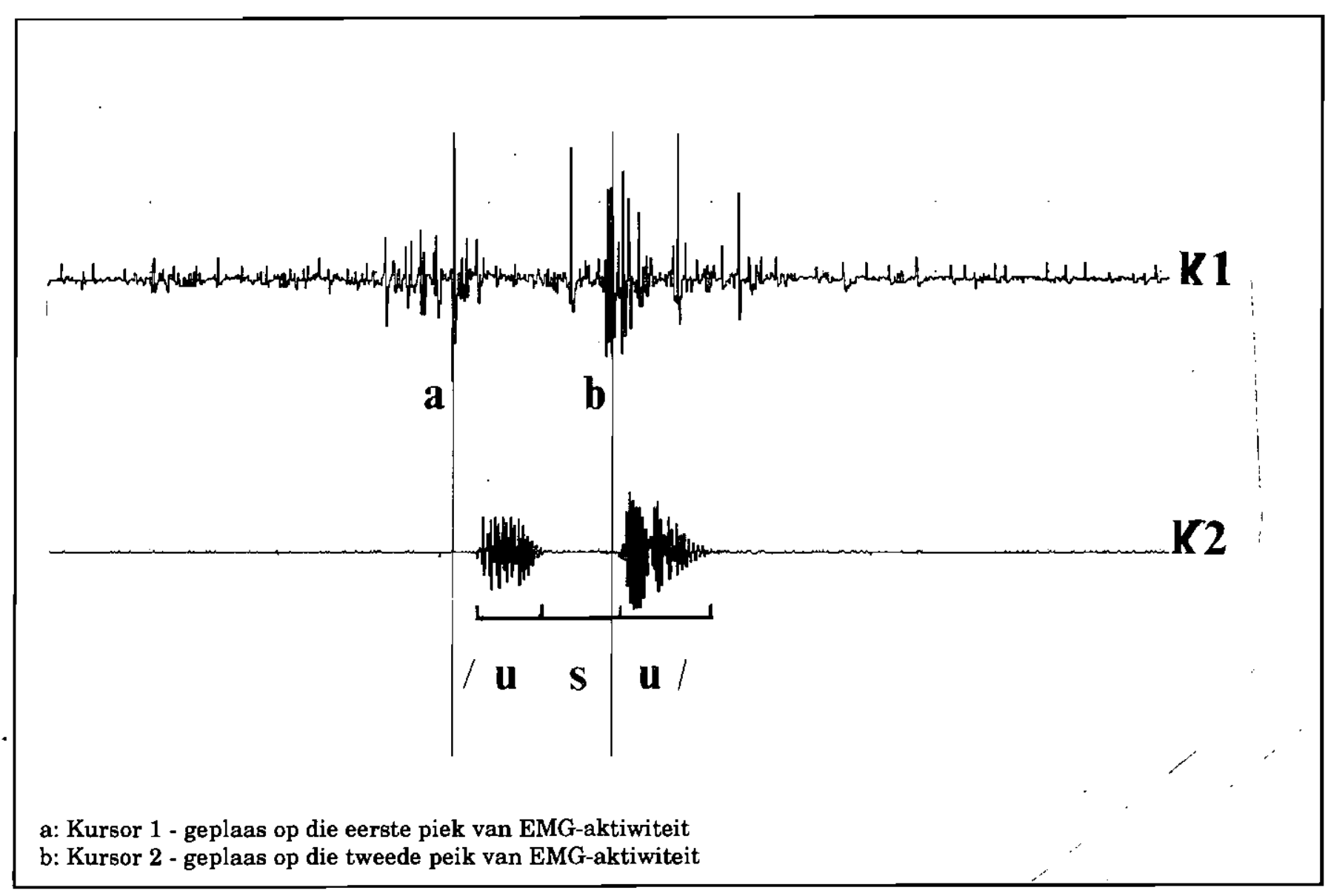

FIGUUR 6: Rekenaaruitdruk vanaf Medelec Mystro MS25 ter illustrasie van die keepverskynsel. 
dat labiale EMG-aktiwiteit al voor of gedurende die eerste i/ begin en voortduur oor die woordgrens. Volgens die gannames van Kozhevnikov en Chistovich (in Kent \& Minifie, 1977) se artikulatoriese lettergreepmodel, behoort die lettergreepgrens die aanvang van labiale ronding geïnhibeer het (Bell-Berti \& Harris, 1979) en verder moes geen ronding al gedurende die /i/ voorgekom het nie.

\section{GEVOLGTREKKING}

$\mathrm{Na}$ aanleiding van die resultate van die studie blyk dit dat nie die artikulatoriese lettergreep model van Kozhevnikov en Chistovich (in Kent \& Minifie, 1977) of die bespiedingsmodel van Henke (in Kent \& Minifie, 1977) ten volle ondersteun word nie. Sussman en Westbury (1981) het egter 'n bespiedingsmeganisme vir die beplanning van spraak voorgestel wat deur die resultate van die huidige studie ondersteun word. Hierdie navorsers meen dat ' $n$ voldoende model van antisiperende koartikulasie 'n teoretiese beskrywing van 'n kenmerkbespiedingsmeganisme vir spraak moet bied wat aan sekere vereistes voldoen. Eerstens moet die meganisme in staat wees om komende artikulatoriese kenmerke wat lank na die huidige opdragte voorkom, te antisipeer. Tweedens moet die meganisme geen vaste tydsgebonde verhouding tot' $n$ fonetiese of abstrakte linguistiese entiteit soos 'n kenmerk of 'n foneem hê nie. Die feit dat gevind is dat die omvang van antisiperende labiale koartikulasie wissel na gelang konsonantstringtyd wissel, impliseer dat daar geen sodanige vaste tydsgebonde verhouding bestaan nie. Derdens moet die meganisme se temporale program aangepas word om die biomeganiese vereistes van die perifere strukture, a.g.v. antagonistiese voorafgaande kontekste, te hanteer. Die feit dat antisiperende labiale koartikulasie reeds gedurende die vokaal /i/ wat 'n negatiewe waarde t.o.v. ronding het voorkom, impliseer dat aanpassings gemaak word om die antagonistiese beweging van die lippe vir die $/ \mathrm{i} /$ te akkomodeer. Vierdens moet die meganisme nie die bespiedingsvermoë gebruik wanneer'n foneem met'n spesifieke kenmerk bv. ronding, twee maal ná mekaar voorkom en geskei word deur'n segment wat neutraal is t.o.v. hierdie kenmerk nie. Die resultate van die huidige studie ondersteun ook hierdie aanname, aangesien antisiperende labiale koartikulasie afwesig was in die $\mathrm{V}_{\mathrm{g}} \mathrm{K}_{\mathrm{nl}} \mathrm{V}_{\mathrm{g}}$-konteks. Die model van Sussman en Westbury (1981) verklaar egter net koartikulasie m.b.t. ronding, terwyl die beplanning van spraak alle eienskappe betrek. Dit sou dus nodig wees om ander tipes koartikulasie, bv. vélêr, mandibulêr of linguaal, te bestudeer m.b.t. ander kenmerke bv. nasaliteit, strekking e.a. om sodoende 'n omvattende model vir die beplanning van spraak deur die brein te formuleer.

Die resultate van die studie ondersteun dus resultate van vele ander navorsers. Uit die resultate van die huidige studie blyk dat Afrikaaanssprekende persone dieselfde reageer m.b.t. die verskynsel van antisiperende labiale koartikulasie, as sprekers van ander tale. Die bevinding dui daarop dat die wyse van motoriese beplanining van spraak 'n universele verskynsel is. Verder dra die resultate van die studie by tot kennis aangaande antisiperende labiale koartikulasie en verskaf dit addisionele data aangaande dié aspekte van koartikulasie waaroor daar steeds kontroversie bestaan. Afleidings uit die resultate van alle navorsers m.b.t. die beplanning van spraak deur die brein is hipoteties en dit is moeilik om betroubare afleidings te maak as die geweldige kompleksiteit en wye omvang van spraakbeplanning in gedagte gehou word.

\section{VERWYSINGS}

Bell-Berti, F, \& Harris, K.S. (1974). More on the motor organization of speech gestures. Haskins Laboratories Status Report on Speech Research, SR-37/38, 73-77.

Bell-Berti, F. \& Harris, K.S. (1979). Anticipatory coarticulation: Some implications from a study of liprounding. Journal of the Acoustical Society of America. 65, 1268-1270.

Bell-Berti, F. \& Harris, K.S. (1981). A temporal model of speech production. Phonetica, 38, 9-20.

Bell-Berti, F. \& Harris, K.S. (1982). Temporal patterns of coarticulation: Liprounding. Journal of the Acoustical Society of America, 71, 449-454.

Benguerel, A.P. \& Cowan, H.A. (1974). Coarticulation of upper lip protrusion in French. Phonetica, 30, 41-55.

Blair, C. \& Smith, A. (1986). EMG Recording in human lip muscles: Can single muscles be isolated? Journal of Speech and Hearing Research, 29, 256-266.

Borden, G.J. \& Harris, K.S. (1984). Speech science primer: Physiology, acoustics and perception of speech. 2de uitgawe, Baltimore: Williams en Wilkens.

Daniloff, R.G. \& Moll, K.L. (1968). Coarticulation of liprounding. Journal of Speech and Hearing Research, 11, 707-721.

Gay, T. (1979). Coarticulation in some consonant-vowel and consonant cluster-vowel syllables. In B. Lindblom \& S. Ohman (Reds.) Frontiers of Speech Communication Research. New York: Academic.

Guy, R.F., Edgley, C.E. Arafat, I. \& Allen, D.E. (1987). Social Research Methods. Puzzles and Solutions. Allyn and Bacon, Inc.

Harris, K.S. (1984). Coarticulation as a component in articulatory description. Haskins Laboratories: Status Report on Speech Research, SR-79, 19-36.

Katz, W.F. (1988a). Anticipatory coarticulation in aphasia: Acoustic and perceptual data. Brain and Language, 35, 340368 .

Katz, W.F. (1988b). "Methodological considerations" reconsidered: Reply to Sussman et al., Brain and Language, 35, 380-385.

Katz, W., Machetanz, J., Schönle, P. \& Orth, U. (1990). A kinematic analysis of anticipatoy coarticulation in speech of anterior aphasic subjects using electromagnetic articulography. Brain and Language, $38,555-575$.

Kent, R.D. \& Minifie, F.D. (1977). Coarticulation in recent speech production models. Journal of Phonetics, $5,115-133$.

Lubker, J. (1981). Temporal aspects of speech production: Anticipatory labial coarticulation. Phonetica, 38, 51-65.

Lubker, J. \& Gay, T. (1982). Anticipatory labial coarticulation: Experimental, biological and linguistic variables. Journal of the Acoustical Society of America, 71, 437-448.

McAllister, R., Lubker, J. \& Carlson, J. (1974). An EMG study of some characteristics of Swedish rounded vowels. Journal of Phonetics, 2, 267-278.

McLean, M. (1973). Forward coarticulation of velar movement at marked junctural boundaries. Journal of Speech and Hearing Research, 16, 286-296.

Sussman, H.M., Marquardt, T.P., McNeilage, P.F. \& Hutchinson, J.A. (1988). Anticipatory coarticulation in aphasia: Some methodological considerations. Brain and Language, 35, 367 379.

Sussman, H.M. \& Westbury, J.R. (1981). The effects of antagonistic gestures on temporal and amplitude parameters of aniticipatory labial coarticulation. Journal of Speech and Hearing Research, 22, 16-46.

Van der Merwe, A. (1986). Die motoriese beplanning van spraak by verbale apraksie. Ongepubliseerde D.Phil-verhandeling. Universiteit van Pretoria. 
BYLAE 1

Roudata wat konsonantstringtyd en antisiperingstyd vir die onderskeie uitings van die vyf proefpersone aandui

\begin{tabular}{|c|c|c|c|c|c|c|c|c|c|c|}
\hline \multirow{2}{*}{$\begin{array}{l}\text { Uiting } \\
\text { Proefpersoon }\end{array}$} & \multicolumn{5}{|c|}{$\begin{array}{c}\text { Konsonantstringtyd (x) } \\
\text { (ms) }\end{array}$} & \multicolumn{5}{|c|}{$\begin{array}{l}\text { Antisiperingstyd (y) } \\
(\mathrm{ms})\end{array}$} \\
\hline & 1 & 2 & 3 & 4 & 5 & 1 & 2 & 3 & 4 & 5 \\
\hline /isi/ & 276 & 192 & 206 & 154 & 212 & 184 & 230 & 306 & 230 & 246 \\
\hline /istu/ & 292 & 226 & 192 & 256 & 300 & 608 & 420 & 432 & 266 & 410 \\
\hline /istsu/ & 442 & 404 & 404 & 464 & 600 & 780 & 490 & 852 & 284 & 632 \\
\hline /iststu/ & 694 & 586 & 412 & 578 & 650 & 790 & 432 & 874 & 432 & 562 \\
\hline /ikststu/ & 800 & 668 & 486 & 604 & 664 & $\overline{116}$ & 256 & 950 & 616 & 544 \\
\hline /is $\supset /$ & 276 & 424 & 208 & 166 & 158 & 520 & 144 & 190 & 164 & 348 \\
\hline /ist / & 458 & 316 & 194 & 220 & 198 & 714 & 206 & 238 & 290 & 342 \\
\hline /ists & 574 & 476 & 388 & 254 & 560 & 886 & 206 & 248 & 166 & 704 \\
\hline /istst & 670 & 524 & 516 & 502 & 604 & 854 & 284 & 718 & 522 & 508 \\
\hline /ikstst & 630 & 640 & 550 & 520 & 664 & 780 & 162 & 688 & 604 & 296 \\
\hline /gistul/ & 230 & 218 & 216 & 170 & 188 & 366 & 144 & 514 & 200 & 414 \\
\hline /dis//tuld/ & 350 & 254 & 318 & 224 & 320 & 462 & 182 & 332 & 302 & 492 \\
\hline /gistut/ & 238 & 410 & 216 & 190 & 192 & 400 & 184 & 326 & 234 & 292 \\
\hline /dis//tutərs/ & 320 & 488 & 304 & 254 & 300 & 518 & 186 & 390 & 528 & 334 \\
\hline /gistup/ & 308 & 204 & 228 & 224 & 226 & 500 & 222 & 482 & 358 & 462 \\
\hline /dis//tupa/ & 326 & 188 & 332 & 190 & 282 & 386 & 206 & 454 & 222 & 474 \\
\hline /gis $\supset \mathrm{f} /$ & 236 & 194 & 236 & 190 & 216 & 376 & 238 & 322 & 336 & 304 \\
\hline$/ \mathrm{dis} / / \mathrm{t} \supset \mathrm{fis} /$ & 376 & 190 & 232 & 160 & 242 & 504 & 228 & 592 & 252 & 412 \\
\hline /gis $\supset$ l/ & 334 & 168 & 98 & 190 & 224 & 548 & 198 & 392 & 238 & 384 \\
\hline$/ \mathrm{dis} / / \mathrm{t} \supset \mathrm{l} \partial /$ & 340 & 190 & 863 & 188 & 230 & 1002 & 222 & 242 & 280 & 416 \\
\hline /gis $\supset \mathrm{m} /$ & 290 & 208 & 214 & 206 & 180 & 406 & 226 & 316 & 502 & 396 \\
\hline
\end{tabular}

